\title{
Peningkatan Imunitas Benih Ikan Gurame (Osphronemus gouramy Lac.) Terhadap Bakteri Aeromonas hydrophila Menggunakan Rosella (Hibiscus sabdariffa L.).
}

\author{
Increased Immunity of Giant Gouramy (Osphronemus gouramy Lac.) Fry Against \\ Aeromonas hydrophila Bacteria Used Roselle (Hibiscus sabdariffa L.).
}

\author{
Fredi Susandi, Mulyana dan Rosmawati
}

\begin{abstract}
The aim of this research is to know the dosage of roselle that produce the best immunity of giant gouramy fry that had been challenged by using Aeromonas hydrophila bacteria. This research has been used two steps. The First step of research is determination of $\mathrm{LD}_{50}$ for 96 hours and was using completely randomized design with 5 treatments and 3 replications. The dosage of Aeromonas hydrophila bacteria is used in the $\mathrm{LD}_{50}$ test were $10^{4}$ cell $/ \mathrm{mL}, 10^{5}$ cell $/ \mathrm{mL}$, $10^{6} \mathrm{cell} / \mathrm{mL}, 10^{7} \mathrm{cell} / \mathrm{mL}$ and control $(0 \mathrm{cell} / \mathrm{mL})$. The mortality of giant gouramy fry had been evaluated. On the second step of research, the giant gouramy fry is reared for 30 days and fed based on according the treatments. The treatments are $20 \mathrm{~g}$ of roselle $/ \mathrm{kg}$ of feed, $30 \mathrm{~g}$ of roselle $/ \mathrm{kg}$ of feed and control ( $0 \mathrm{~g}$ of roselle/ $\mathrm{kg}$ of feed), each treatment repeated 4 times. Every fish fry is challenged with using $10^{3}$ cell of Aeromonas hydrophila on the first challenged test and $10^{4}$ cell of Aeromonas hydrophila on the second challenged test treatmen to determination of the best imunity. The mortality, total leucocyte, total erithrocyte, haemoglobin, haematocrite and phagositic index had been evaluated. The results showed that $\mathrm{LD}_{50}$ of Aeromonas hydrophila bacteria is $10^{4}$ cell $/ \mathrm{mL}$. The second step of research showed there were the most significantly different $(\mathrm{P}<0.01)$ to mortality of giant gouramy fry. The best dosagee of roselle is $30 \mathrm{~g}$ of roselle $/ \mathrm{kg}$ of feed with $8.26 \%$ of mortality, total leucocyte $6.873 \times 10^{5} \mathrm{sel} / \mathrm{mm}^{3}$, total eritrocyte $2.043 \times 10^{6} \mathrm{sel} / \mathrm{mm}^{3}$, haemoglobin $6.55 \mathrm{~g} \%$, haematocrite $20.59 \%$ and phagositic index $64 \%$.
\end{abstract}

\section{Keywords :}

\section{ABSTRAK}

Penelitian ini bertujuan untuk mengetahui dosis rosella yang menghasilkan imunitas benih ikan Gurame yang diuji tantang dengan menggunakan bakteri Aeromonas hydrophila. Penelitian ini menggunakan dua tahap. Penenlitian tahap pertama adalah penentuan $\mathrm{LD}_{50}$ selama 96 jam dan menggunakan rancangan acak lengkap dengan 5 perlakuan dan 3 ulangan. Dosis bakteri A. hydrophila yang digunakan pada uji $\mathrm{LD}_{50}$ adalah $10^{4} \mathrm{cell} / \mathrm{mL}, 10^{5}$ cell $/ \mathrm{mL}, 10^{6} \mathrm{cell} / \mathrm{mL}, 10^{7}$ cell $/ \mathrm{mL}$ dan Kontrol ( 0 cell $/ \mathrm{mL}$ ). Mortalitas benih ikan Gurame dievaluasi. Pada penelitian tahap kedua, benih ikan Gurame dipelihara selama 30 hari dan diberi pakan berdasarkan perlakuan. Perlakuannya adalah A (Kontrol, $0 \mathrm{~g}$ rosella/kg pakan), B (20 g rosella/kg pakan), dan C (30 g rosella/kg pakan). Setiap perlakuan diulang 4 kali. Setiap ekor ikan Gurame diuji tantang dengan menggunakan $10^{3}$ sel Aeromonas hydrophila pada uji tantang pertama dan $10^{4}$ sel Aeromonas hydrophila pada uji tantang kedua untuk penentuan imunitas terbaik. Mortalitas, total leukosit, total eritrosit, hemoglobin, hematokrit dan indeks fagositik dievaluasi. Hasil penelitian memperlihatkan bahwa $\mathrm{LD}_{50}$ adalah $10^{4} \mathrm{sel} / \mathrm{mL}$. Penelitian tahap kedua memperlihatkan adanya perbedaan saangat nyata $(\mathrm{P}<0,01)$ diantara perlakuan terhadap mortalitas benih ikan Gurame. Dosis rosella terbaik adalah $30 \mathrm{~g}$ rosella/kg pakan dengan mortalitas ikan Grame sebesar 8,26\%, total leukosit $6,873 \times 10^{5} \mathrm{sel} / \mathrm{mm}^{3}$, total eritrosit $2,043 \times 10^{6} \mathrm{sel} / \mathrm{mm}^{3}$, hemoglobin $6,55 \mathrm{~g} \%$, hematokrit 20,59\% dan indeks fagositik $64 \%$.

\section{Kata Kunci :}

Fredi Susandi, Mulyana, Rosmawati. 2017. Peningkatan Imunitas Benih Ikan Gurame (Osphronemus gouramy Lac). Jurnal Mina Sains 3(2): 1-12. 


\section{PENDAHULUAN}

\section{Latar Belakang}

Ikan gurami merupakan ikan asli perairan Indonesia dan merupakan ikan air tawar yang bernilai jual tinggi, sehingga memberikan dampak positif dengan berkembangnya usaha budidaya ikan gurami. Ikan gurami termasuk ikan yang relatif tahan terhadap serangan hama penyakit. Namun, bukan berarti pembudidayaan ikan gurami sepenuhnya terbebas dari ancaman serangan hama penyakit (Khairuman dan Amri 2011). Salah satu serangan panyakit yang sangat diwaspadai adalah serangan dari bakteri Aeromonas hydrophila yang dapat menyebabkan MAS (Motile Aeromonas Septicemia) atau yang lebih dikenal sebagai penyakit bercak merah. Ikan yang terkena penyakit bercak merah ini ditandai dengan adanya gejala pendarahan atau luka pada bagian kulit dan bagian tubuh lainnya, bila serangannya parah luka itu akan menjadi borok yang berwarna merah, perut membusung dan organ dalam ikan seperti hati, ginjal dan limpa akan tampak pendarahan. Penyakit ini tidak hanya menyerang ikan gurami saja, melainkan ikan air tawar lainnya seperti sidat, ikan mas, nila dan lele (Sasongko et al. 2007). Afrianto dan Liviawati (1999) menyebutkan bahwa pada tahun 1980 terjadi serangan bakteri Aeromonas di Jawa Barat dan mematikan puluhan ton ikan.

Pada umumnya untuk mengontrol penyakit yang disebabkan Aeromonas hydrophila yaitu menggunakan antibiotik, namun di sisi lain penggunaan antibiotik atau antibakteri pada budidaya akan meningkatkan jumlah bakteri yang resistan terhadap antibiotik yang dipakai (Chrisanti et al. 2012). Untuk menanggulangi permasalah tersebut maka diperlukan upaya alternatif yang harus dilakukan oleh para pelaku usaha budidaya ikan gurami yaitu meningkatkan daya tahan tubuh ikan gurami dengan menggunakan bahan alami yang relatif lebih aman daripada menggunakan bahan kimia. Salah satu bahan alami yang secara empiris dapat menyembuhkan berbagai macam penyakit, berfungsi sebagai anti bakteri dan imunostimulan adalah bunga rosella (Hibiscus sabdariffa L.). Bunga rosella mengandung kalsium, vitamin C, D, B1, B2, magnesium, Omega-3, beta-caroten dan 18 asam amino essensial. Kandungan vitamin $\mathrm{C}$ yang ada pada bunga rosella tiga kali lipat dari anggur hitam, 9 kali lipat dari jeruk citrus dan 10 kali lipat dari buah belimbing (Neni 2010). Mustikhasary (2013) membuktikan bahwa penggunaan bunga rosella dapat meningkatkan sistem ketahanan tubuh ikan gurami yang terserang bakteri Aeromonas hydrophila, walaupun rataan kadar hematokrit dan indeks pagositik masih rendah karena ikan mengalami stress dan air ber-pH rendah. Oleh karena itu, perlu dikaji kembali penambahan rosella dalam pakan untuk meningkatkan ketahanan tubuh ikan dengan meningkatkan kualitas air.

\section{Tujuan Penelitian}

Penelitian ini bertujuan untuk mengetahui dosis bunga rosella (Hibiscus sabdariffa L) terhadap peningkatan daya imunitas ikan gurami terhadap serangan bakteri Aeromonas hydrophila.

\section{Hipotesis}

Semakin tinggi dosis bunga rosella sampai batas tertentu pada pakan akan meningkatkan ketahanan tubuh ikan gurami terhadap infeksi Aeromonas hydrophila.

\section{BAHAN DAN METODE \\ Waktu dan Tempat}

Penelitian ini dilaksanakan pada bulan Maret sampai Juni 2013, bertempat di Laboraturium Perikanan, Universitas Djuanda Bogor dan di Laboratorium Kesehatan Ikan IPB, Bogor. Penelitian ini dilakukan dalam 2 tahap, yaitu penentuan lethal dosis dan uji tantang.

\section{Penelitian Tahap Pertama}

Penelitian tahap pertama bertujuan untuk mengetahui lethal dosis $50\left(\mathrm{LD}_{50}\right)$. Hasil dari $\mathrm{LD}_{50}$ ini merupakan dosis bakteri yang akan digunakan untuk uji tantang pada penelitian tahap kedua.
Alat dan Bahan
a. Wadah : 15 akuarium berukuran 30 x 30 x $30 \mathrm{~cm}^{3}$.
b. Ikan : 300 ekor benih ikan gurami ukuran 6-9 gram. 
c. Pakan : Pellet komersil dan bunga rosella.

d. Bakteri : Aeromonas hydrophilla.

\section{Rancangan Percobaan}

Rancangan percobaan penentuan lethal dosis menggunakan Rancangan Acak Lengkap (RAL), dengan 5 perlakuan dan 3 kali ulangan. Satu satuan percobaan adalah satu akuarium berukuran $30 \times 30 \times 30 \mathrm{~cm}^{3}$ yang diisi air sebanyak 23,5 liter dengan jumlah ikan sebanyak 20 ekor. Benih ikan gurami diinfeksi bakteri Aeromonas hydrophila dengan konsentrasi yang berbeda dan masing-masing perlakuan diulang 3 kali. Perlakuan yang diberikan yaitu :

Perlakuan A (ikan tanpa diinfeksi bakteri $A$. hydrophila ), Perlakuan B (ikan diinfeksi bakteri $A$. hydrophila dengan konsentrasi $10^{4}$ sel/mL), Perlakuan C (ikan diinfeksi bakteri $A$. hydrophila dengan konsentrasi $10^{5} \mathrm{sel} / \mathrm{mL}$ ), Perlakuan D (ikan diinfeksi bakteri $A$. hydrophila dengan konsentrasi $10^{6} \mathrm{sel} / \mathrm{mL}$ ), dan Perlakuan E (ikan diinfeksi bakteri $A$. hydrophila dengan konsentrasi $10^{7} \mathrm{sel} / \mathrm{mL}$ ).

Model persamaan linier berdasarkan Steel dan Torrie (1991) adalah sebagai beriukut :

Keterangan :

$$
\mathbf{Y}_{\mathrm{ij}}=\boldsymbol{\mu}+\boldsymbol{\delta}_{\mathrm{i}}+\varepsilon_{\mathrm{ij}}
$$

$\mathrm{Y}_{\mathrm{ij}}=$ Data hasil pengamatan pada perlakuan ke-i dan ulangan ke-j

$\mu=$ Nilai tengah dari populasi

$\delta_{\mathrm{i}}=$ Pengaruh perlakuan ke-i

$\varepsilon_{\mathrm{ij}}=$ Galat perlakuan ke-i dan ulangan ke-j

$\mathrm{i}=\operatorname{Perlakuan}(\mathrm{I}=\mathrm{A}, \mathrm{B}, \mathrm{C}, \mathrm{D}, \mathrm{E})$

$\mathrm{j} \quad=$ Ulangan $(\mathrm{j}=1,2,3)$

\section{Prosedur Percobaan}

Penentuan lethal dosis dilakukan sebelum uji tantang benih ikan gurami yang sudah dipelihara dan diberi perlakuan pakan. Lethal dosis yang digunakan adalah lethal dosis $50\left(\mathrm{LD}_{50}\right)$.

Wadah yang digunakan adalah akuarium berukuran $30 \times 30$ x $30 \mathrm{~cm}^{3}$, akuarium dibersihkan dan diisi air sebanyak 23,5 liter. Air yang digunakan merupakan air sumur yang telah diendapkan dan diaerasi di tandon. Pemasangan aerasi pada masing-masing akuarium bertujuan untuk meningkatkan kadar oksigen terlarut (DO) dalam air dan pemasangan heater untuk menjaga kestabilan suhu pada kisaran $28-30{ }^{\circ} \mathrm{C}$.

Benih ikan gurami berukuran 6-9 gram diseleksi dan ditempatkan pada akuarium berukuram $30 \times 30 \times 30 \mathrm{~cm}^{3}$. Selanjutnya, benih ikan gurami diinfeksi menggunakan bakteri A. hydrophila secara intramuscular (pada otot punggung) sebanyak $0,1 \mathrm{~mL} / \mathrm{ekor}$. Dosis bakteri yang diinfeksikan sesuai perlakuan yang diberikan. Pengamatan dilakukan selama 96 jam dengan mencatat waktu kematian ikan dan menghitung mortalitas ikan. Untuk menjaga kualitas dilakukan penyiponan secara berkala sebanyak $50 \%$ dari total air dalam akuarium dan menambahkan kembali air dari tandon ke akuarium sebanyak yang diperlukan.

\section{Parameter yang Diamati}

Parameter yang diamati pada penentuan $\mathrm{LD}_{50}$ adalah mortalitas.

\section{Analisis Data}

Mortalitas dianalisis secara deskriptif (kualitatif).

\section{Penelitian Tahap Kedua}

Penelitian tahap kedua adalah uji tantang benih ikan gurami dengan menggunakan bakteri Aeromonas hydrophila. Dosis bakteri Aeromonas hydrophila yang digunakan adalah dosis hasil dari penentuan lethal dosis $50\left(\mathrm{LD}_{50}\right)$.

Sebelum uji tantang dilakukan, benih ikan gurami ukuran 3-4 gram dipelihara pada akuarium berukuran $50 \times 30 \times 30 \mathrm{~cm}^{3}$ sebanyak 30 ekor per akuarium selama 30 hari dan diberi perlakuan penambahan rosella dengan dosis berbeda pada pakan buatan. Pemberian pakan dilakukan secara ad libitum dengan frekuensi pemberian pakan dilakukan dua kali sehari yaitu pagi hari jam 08.00 dan sore hari $16.00 \mathrm{WIB}$.
Alat dan Bahan
a. Wadah
: 12 akuarium berukuran 50 x $30 \times 30 \mathrm{~cm}^{3}$.
b. Ikan
: 480 ekor benih ikan
c. Pakan gurami ukuran 3-4 gram.
d. Imunostimulan : Rosella 
e. Bakteri

: Aeromonas hydrophilla.

\section{Rancangan Percobaan}

Rancangan percobaan uji tantang menggunakan Rancangan Acak Lengkap (RAL), dengan 3 perlakuan dan 4 kali ulangan. Satu satuan percobaan adalah satu akuarium berukuran $50 \times 30 \times 30 \mathrm{~cm}^{3}$ yang diisi air sebanyak 37,5 liter dengan jumlah ikan sebanyak 40 ekor. Perlakuan yang diberikan adalah penambahan rosella pada pakan buatan dengan dosis yang berbeda dan masing-masing perlakuan diulang 4 kali. Semua perlakuan diuji tantang dengan menggunakan bakteri $A$. hydrophila. Perlakuan yang diberikan yaitu : Perlakuan A (pakan tanpa penambahan rosella), Perlakuan B (pakan dengan panambahan rosella $20 \mathrm{~g} / \mathrm{kg}$ ), dan Perlakuan C (pakan dengan panambahan rosella $30 \mathrm{~g} / \mathrm{kg}$ ).

Model persamaan linier berdasarkan Steel dan Torrie (1991) adalah sebagai berikut:

Keterangan :

$$
\mathbf{Y}_{\mathrm{ij}}=\boldsymbol{\mu}+\boldsymbol{\delta}_{\mathrm{i}}+\boldsymbol{\varepsilon}_{\mathrm{ij}}
$$

$\mathrm{Y}_{\mathrm{ij}}=$ Data hasil pengamatan pada perlakuan ke-i dan ulangan ke-j

$\mu=$ Nilai tengah dari populasi

$\delta_{\mathrm{i}}=$ Pengaruh perlakuan ke-i

$\varepsilon_{\mathrm{ij}}=$ Galat perlakuan ke-i dan ulangan ke-j

$\mathrm{i}=$ Perlakuan $(\mathrm{i}=\mathrm{X}, \mathrm{Y}, \mathrm{Z}$,

$\mathrm{j} \quad=$ Ulangan $(\mathrm{j}=1,2,3)$

\section{Prosedur Percobaan}

Persiapan uji tantang dimulai dengan membersihkan 12 akuarium berukuran berukuran $50 \quad$ x $30 \quad$ x $30 \quad \mathrm{~cm}^{3}$ dengan menggunakan air bersih dan dikeringkan selama 24 jam. Selanjutnya, akuarium yang sudah kering diletakkan pada rak kayu yang sudah disiapkan dan diisi air sebanyak 37,5 liter dengan menggunakan air tandon. Akuarium yang sudah tersusun rapi selanjutnya dilakukan pemasangan instalasi aerasi untuk meningkatkan kandungan oksigen terlarut (DO) dalam air, pemasangan heater agar suhu air pada akurium uji stabil pada kisaran $28-30^{\circ} \mathrm{C}$.

Air yang digunakan selama penelitian berasal dari sumber air tanah (sumur), sebelum digunakan air tersebut diendapkan dan diaerasi terlebih dahulu selama tiga hari. Untuk menjaga kualitas air dalam akuarium selama pemeliharaan dan uji tantang maka air disipon setiap hari sebanyak $50 \%$ dari total air dalam akuarium dan ditambahkan air kembali dari tandon sebanyak yang diperlukan. Penyiponan dilakukan dengan cara membuang sisa pakan dan hasil metabolisme benih ikan gurami, penyiponan dilakukan pada jam 07.00 WIB sebelum ikan diberi pakan.

Benih ikan gurami yang sudah dipelihara dengan perlakuan penambahan bunga rosella pada pakan dengan dosis berbeda selama 30 hari, kemudian diuji tantang menggunakan bakteri A. hydrophila. Darah ikan diambil sebelum dilakukan uji tantang untuk mengetahui gambaran darah ikan sebelum uji tantang. Ikan diuji tantang menggunakan bakteri A. hydrophila yang disuntikkan kepada benih ikan gurami secara intramuscular (pada otot punggung). Konsentrasi bakteri $A$. hydrophila yang digunakan pada uji tantang adalah konsentrasi hasil dari penentuan lethal dosis $50\left(\mathrm{LD}_{50}\right)$ sebanyak $0,1 \mathrm{ml}$. Ikan yang telah disuntik dimasukkan kembali ke dalam akuarium dan dilakukan pengamatan selama 4 hari terhadap ikan-ikan yang sudah diinfeksi serta menghitung mortalitasnya. Setelah uji tantang selesai maka darah ikan diambil kembali untuk mengetahui gambaran darah setelah uji tantang. Selanjutnya, benih ikan dilakukan uji tantang kedua dengan menggunakan bakteri A. hydrophila dengan dosis ditingkatkan 10 kali lipat dari $\mathrm{LD}_{50}$. Ikan dipelihara lagi selama 4 hari (96 jam), setelah uji tantang kedua selesai, darah ikan diambil kembali untuk mengetahui gambaran darahnya.

\section{Parameter yang Diamati Mortalitas}

Menghitung mortalitas menggunakan rumus sebagai berikut :

$$
\mathrm{Mo}=\frac{\mathrm{Nt}}{\mathrm{No}} \times 100 \%
$$

Keterangan :

Mo $=$ Tingkat kematian ikan (\%)

$\mathrm{Nt}=$ Jumlah ikan mati (ekor)

No = Populasi ikan pada hari ke-0 (ekor)

\section{Gambaran Darah}

Gambaran darah benih ikan gurami yang diamati adalah sebagai berikut : 


\section{Total sel darah putih (Leukosit)}

Perhitungan dilakukan dengan mengencerkan darah dengan larutan Turks di dalam pipet pencampuran berskala maksimum 11. Darah dicampur dengan pipet pencampur hingga skala 0,5 kemudian pipet yang sama dihisap larutan Turks hingga skala 11. Pipet kemudian digoyang membentuk angka delapan selama 3-5 menit agar tercampur secara merata. Sebelum dilakukan perhitungan, larutan pada ujung pipet yang tidak teraduk dibuang, tetesan berikutnya dimasukkan ke dalam haemoisitometer yang telah dilengkapi dengan kaca penutup kemudian diamati dibawah mikroskop (Blaxhall dan Daisley 1973).

\section{Total sel darah merah (Eritrosit)}

Menurut Tim Dosen Fisiologi Hewan UNAIR Surabaya (2008) untuk menghitung jumlah eritrosit, pada prinsipnya sama seperti penghitungan jumlah leukosit, hanya terdapat perbedaan sebagai berikut: Pengenceran darah 100 kali, cairan pengencemya adalah larutan Hayem dan alat pengencernya haemacytometer. Eritrosit yang dihitung adalah sel yang terdapat di dalam bujur sangkar kecil (sebanyak 80 kotak) dengan sisi $1 / 20 \mathrm{~mm}$ atau volume setiap bujur sangkar $1 / 4000 \mathrm{~mm}^{3}$. Cara penghitungan (diamati pada pembesaran mikroskop 10 x 40):

Jumlah bujur sangkar yang dihitung $=80 \mathrm{kali}$

Volume setiap bujur sangkar

$$
=1 / 4000 \mathrm{~mm}^{3}
$$

Darah yang diencerkan

$$
=100 \mathrm{kali}
$$

Jumlah eritrosit yang terhitung

$$
=\mathrm{E}
$$

Maka jumlah eritrosit per $\mathrm{mm}^{3}$

$$
=\mathrm{E} / 80 \times 4000 \times 100
$$

\section{Hemoglobin (Hb)}

Konsentrasi hemoglobin diukur menggunakan metode Sahli. Sampel darah ikan diambil dengan pipet sahli sampai skala $20 \mathrm{~mm}^{3}$. Ujung pipet yang digunakan dibersihkan dari sisa-sisa darah dengan kertas tissue. Darah dipindahkan ke dalam tabung sahli yang telah diisi dengan $\mathrm{HCl} 0,1 \mathrm{~N}$ sampai angka 10 (garis skala paling bawah pada tabung sahli). Kemudian tabung tersebut ditempatkan diantara 2 tabung yang berisi warna standar. Akuades ditambahkan ke dalam tabung sahli sedikit demi sedikit menggunakan pipet, sampai warnanya sama dengan warna standar, dan hasilnya dinyatakan dalam gr\% (Hesser 1960).

\section{Kadar hamatokrit (Ht)}

Sampel darah ikan dihisap menggunakan tabung mikrohematokrit berlapis heparin dengan kapiler. Fungsi heparin adalah untuk mencegah pembekuan darah di dalam tabung. Setelah darah mencapai $3 / 4$ bagian tabung, kemudian salah satu ujung tabung disumbat dengan critoseal. Tabung kapiler yang berisi darah kemudian disentrifusi pada $600 \mathrm{rpm}$ selama 5 menit. Pengukuran dilakukan dengan membandingkan volume sel darah terhadap volume seluruh darah dengan menggunakan skala hematokrit (Anderson dan Siwicky 1993).

\section{Analisis Data}

Mortalitas dianalisis dengan analisis sidik ragam atau ANOVA (Analisys of Variance) menggunakan perangkat lunak Microsoft Exel 2013 pada selang kepercayaan 99\% dan jika berbeda nyata dilanjutkan dengan uji lanjut Beda Nyata Terkecil (BNT) pada selang kepercayaan $99 \%$ untuk melihat perbedaan antar perlakuan. Sedangkan gambaran darah dianalisis secara deskriptif (kualitatif).

\section{Hasil}

\section{HASIL DAN PEMBAHASAN}

Hasil dari penelitian tahap pertama mengenai penentuan lethal dosis $50\left(\mathrm{LD}_{50}\right)$ ikan gurami terhadap Aeromonas hydrophila pada tanggal 11-15 April 2013 adalah mortalitas. Pada penelitian tahap kedua mengenai peningkatan imunitas ikan gurami terhadap Aeromonas hydrophila dengan menambahkan bunga rosella pada pakan buatan pada tanggal 6 Mei-12 Juni 2013 diperoleh hasil meliputi : tingkat kematian (mortalitas), total sel darah putih, total sel darah merah, hemoglobin, kadar hematocrit dan Indeks Fagositik. 
Lethal Dosis $50 \quad\left(\mathbf{L D}_{50}\right)$ Aeromonas hydrophila Terhadap Gurami

Hasil pengamatan $\mathrm{LD}_{50}$ selama 96 jam memperlihatkan tingkat kematian benih ikan gurami yang berbeda seperti terlihat pada Tabel 1.

Tabel 1. Mortalitas benih gurami pasca penyuntikan Aeromonas hydrophila
Mortalitas Benih Gurami Pasca Penyuntikan Dengan Aeromonas hydrophila

Mortalitas pada uji tantang pertama dapat dilihat pada Tabel 2. Mortalitas pada uji tantang kedua dapat dilihat pada Tabel 3.

\begin{tabular}{cccccc}
\hline & \multicolumn{5}{c}{ Perlakuan (Dosis bakteri Aeromonas hydrophila) } \\
\cline { 2 - 6 } Ulangan & $\mathrm{A}$ & $\mathrm{B}$ & $\mathrm{C}$ & $\mathrm{D}$ & $\mathrm{E}$ \\
& $($ Kontrol) & $\left(10^{4}\right.$ & $\left(10^{5} \mathrm{sel} / \mathrm{mL}\right)$ & $\left(10^{6}\right.$ & $\left(10^{7}\right.$ \\
& & $\mathrm{sel} / \mathrm{mL})$ & & $\mathrm{sel} / \mathrm{mL})$ & $\mathrm{sel} / \mathrm{mL})$ \\
\hline $\mathbf{1}$ & $0 \%$ & $60 \%$ & $95 \%$ & $95 \%$ & $100 \%$ \\
$\mathbf{2}$ & $5 \%$ & $55 \%$ & $90 \%$ & $90 \%$ & $95 \%$ \\
$\mathbf{3}$ & $0 \%$ & $75 \%$ & $90 \%$ & $75 \%$ & $100 \%$ \\
\hline Rataan & $1,67 \%$ & $63,33 \%$ & $91,67 \%$ & $86,67 \%$ & $98,33 \%$ \\
\hline
\end{tabular}

Tabel 2. Mortalitas (\%) benih ikan gurami pada uji tantang pertama

\begin{tabular}{cccc}
\hline Ulangan & \multicolumn{3}{c}{ Dosis rosella } \\
\cline { 2 - 4 } & $\begin{array}{c}\mathrm{A} \\
\text { (tanpa rosella) }\end{array}$ & $\begin{array}{c}\mathrm{B} \\
\text { (rosella } 20 \mathrm{~g} / \mathrm{Kg} \text { Pakan) }\end{array}$ & $\begin{array}{c}\mathrm{C} \\
\text { (rosella 30 g/Kg Pakan) }\end{array}$ \\
\hline $\mathbf{1}$ & 16,67 & 0 & 0 \\
$\mathbf{2}$ & 16,67 & 0 & 0 \\
$\mathbf{3}$ & 16,67 & 0 & 11,11 \\
$\mathbf{4}$ & 5,56 & 5,56 & 0 \\
\hline Rataan & $13,89^{\mathrm{a}}$ & $1,39^{\mathrm{b}}$ & $2,78^{\mathrm{b}}$ \\
\hline
\end{tabular}

Keterangan : Superskrip huruf yang berbeda menunjukkan perbedaan yang sangat nyata $(\mathrm{P}<0,01)$

Tabel 3. Mortalitas (\%) benih ikan gurami pada uji tantang kedua

\begin{tabular}{cccc}
\hline Ulangan & \multicolumn{3}{c}{ Dosis rosella } \\
\cline { 2 - 4 } & $\mathrm{A}$ & $\mathrm{B}$ & $\mathrm{C}$ \\
& (tanpa rosella) & (rosella 20 g/Kg Pakan) & (rosella 30 g/Kg Pakan) \\
\hline $\mathbf{1}$ & 38,46 & 18,75 & 12,50 \\
$\mathbf{2}$ & 23,08 & 18,75 & 0 \\
$\mathbf{3}$ & 53,85 & 6,25 & 14,29 \\
$\mathbf{4}$ & 26,67 & 20,00 & 6,25 \\
\hline Rataan & $35,51^{\mathrm{a}}$ & $15,94^{\mathrm{ab}}$ & $8,26^{\mathrm{b}}$ \\
\hline
\end{tabular}

Keterangan : Superskrip huruf yang berbeda menunjukkan perbedaan yang sangat nyata $(\mathrm{P}<0,01)$

\section{Total Sel Darah Putih (Leukosit)}

Total leukosit pada benih ikan gurami setelah perlakuan pemberian rosella atau sebelum uji tantang pertama, setelah uji tantang pertama atau sebelum uji tantang kedua dan sesudah uji tantang kedua dapat dilihat pada Tabel 4.

\section{Total Sel Darah Merah (Eritrosit)}

Total eritrosit pada benih ikan gurami setelah perlakuan pemberian rosella atau sebelum uji tantang pertama, setelah uji tantang pertama atau sebelum uji tantang kedua dan sesudah uji tantang kedua dapat dilihat pada Tabel 5.

\section{Konsentrasi Hemoglobin (Hb)}

Konsentrasi hemoglobin pada benih ikan gurami setelah perlakuan pemberian rosella atau sebelum uji tantang pertama, setelah uji tantang pertama atau sebelum uji tantang kedua dan sesudah uji tantang kedua dapat dilihat pada Tabel 6 . 
Tabel 4. Total sel darah putih benih ikan gurami selama penelitian

\begin{tabular}{cccc}
\hline \multirow{2}{*}{ Perlakuan } & \multicolumn{3}{c}{ Total leukosit $\left(\mathbf{x} \mathbf{1 0}^{\mathbf{5}} \mathbf{s e l} / \mathbf{m m}^{\mathbf{3}}\right)$} \\
\cline { 2 - 4 } & $\begin{array}{c}\text { Sebelum uji } \\
\text { tantang pertama }\end{array}$ & $\begin{array}{c}\text { Setelah uji } \\
\text { tantang pertama }\end{array}$ & $\begin{array}{c}\text { Setelah uji } \\
\text { tantang kedua }\end{array}$ \\
\hline A & $\mathbf{4 , 9 2 0}$ & $\mathbf{6 , 4 8 5}$ & $\mathbf{9 , 0 7 3}$ \\
\hline B & $\mathbf{5 , 4 5 0}$ & $\mathbf{6 , 9 3 0}$ & $\mathbf{6 , 0 8 3}$ \\
\hline C & $\mathbf{5 , 2 4 8}$ & $\mathbf{5 , 8 8 8}$ & $\mathbf{6 , 8 7 3}$ \\
\hline
\end{tabular}

Tabel 5. Total sel darah merah benih ikan gurami selama penelitian

\begin{tabular}{|c|c|c|c|}
\hline \multirow[t]{2}{*}{ Perlakuan } & \multicolumn{3}{|c|}{ Total Eritrosit $\left(\times\right.$ 10 $\left.^{6} \mathrm{sel} / \mathrm{mm}^{3}\right)$} \\
\hline & $\begin{array}{c}\text { Sebelum uji } \\
\text { tantang pertama }\end{array}$ & $\begin{array}{c}\text { Setelah uji } \\
\text { tantang pertama }\end{array}$ & $\begin{array}{c}\text { Setelah uji } \\
\text { tantang kedua }\end{array}$ \\
\hline $\mathbf{A}$ & 1,71 & 1,74 & 1,775 \\
\hline $\mathbf{B}$ & 1,608 & 1,703 & 1,720 \\
\hline $\mathbf{C}$ & 1,88 & 1,76 & 2,043 \\
\hline
\end{tabular}

Tabel 6. Konsentrasi hemoglobin benih ikan gurami selama penelitian

\begin{tabular}{cccc}
\hline \multirow{2}{*}{ Perlakuan } & \multicolumn{3}{c}{ Hemoglobin (gram\%) } \\
\cline { 2 - 4 } & $\begin{array}{c}\text { Sebelum uji } \\
\text { tantang pertama }\end{array}$ & $\begin{array}{c}\text { Setelah uji } \\
\text { tantang pertama }\end{array}$ & $\begin{array}{c}\text { Setelah uji } \\
\text { tantang kedua }\end{array}$ \\
\hline A & $\mathbf{4 , 6}$ & $\mathbf{6 , 3}$ & $\mathbf{6 , 2 5}$ \\
\hline B & $\mathbf{4 , 8 5}$ & $\mathbf{6 , 4 5}$ & $\mathbf{5 , 5}$ \\
\hline $\mathbf{C}$ & $\mathbf{4 , 4 5}$ & $\mathbf{5 , 6}$ & $\mathbf{6 , 5 5}$ \\
\hline
\end{tabular}

\section{Kadar Hematokrit (Ht)}

Kadar hematokrit pada benih ikan gurami setelah perlakuan pemberian rosella atau sebelum uji tantang pertama, setelah uji tantang pertama atau sebelum uji tantang kedua dan sesudah uji tantang kedua dapat dilihat pada Tabel 7.

Tabel 7. Kadar hematokrit benih ikan gurami selama penelitian

\begin{tabular}{cccc}
\hline Dosis rosella & \multicolumn{3}{c}{ Hematokrit (\%) } \\
\cline { 2 - 4 } & $\begin{array}{c}\text { Sebelum uji } \\
\text { tantang pertama }\end{array}$ & $\begin{array}{c}\text { Setelah uji } \\
\text { tantang pertama }\end{array}$ & $\begin{array}{c}\text { Setelah uji } \\
\text { tantang kedua }\end{array}$ \\
\hline A & $\mathbf{1 4 , 7 1}$ & $\mathbf{1 7 , 2 0}$ & $\mathbf{1 9 , 2 7}$ \\
\hline B & $\mathbf{1 4 , 3 9}$ & $\mathbf{2 2 , 1 4}$ & $\mathbf{2 1 , 2 3}$ \\
\hline C & $\mathbf{1 6 , 5 0}$ & $\mathbf{2 1 , 7 1}$ & $\mathbf{2 0 , 5 9}$ \\
\hline
\end{tabular}

\section{Kualitas Air}

Kualitas air media pemeliharaan untuk beberapa parameter seperti suhu, oksigen terlarut (DO), ammonia, $\mathrm{pH}$ dan karbondioksida $\left(\mathrm{CO}_{2}\right)$ masih berada pada kisaran yang layak untuk kehidupan benih ikan gurami. Beberapa parameter kualitas air dapat dilihat pada Tabel 8.

\section{Pembahasan}

Lethal Dosis $50 \quad\left(\mathbf{L D}_{50}\right)$ Aeromonas hydrophila Terhadap Gurami

Bakteri Aeromonas

hydrophila merupakan pathogen yang menyebabkan penyakit bercak merah pada ikan. Swann dan White (1995) menegaskan bahwa Motile Aeromonas Septicemia (MAS) atau Hemorrhagic Septicemia disebabkan oleh bakteri $A$. hydrophila. Benih gurami yang telah terinfeksi bakteri $A$. hydrophila pada uji $\mathrm{LD}_{50}$ dapat dilihat pada Gambar 1. 
Tabel 8. Kualitas air selama penelitian

\begin{tabular}{ccccc}
\hline & \multicolumn{3}{c}{ Perlakuan (dosis rosella) } & Tandon \\
\cline { 2 - 4 } Parameter Kualitas Air & $\mathrm{A}$ & $\mathrm{B}$ & $\mathrm{C}$ & \\
& $($ Kontrol) & $(20 \mathrm{~g} / \mathrm{kg}$ pakan) & $(30 \mathrm{~g} / \mathrm{kg}$ pakan) & \\
\hline Suhu $\left(\mathbf{(}^{\mathbf{0}} \mathbf{C}\right)$ & $28-31$ & $28-31$ & $28-31$ & $24-26$ \\
DO $(\mathbf{p p m})$ & $4,22-4,41$ & $4,27-4,52$ & $4,40-4,55$ & 3,78 \\
$\mathbf{p H}$ & $7,0-7,4$ & $7,0-7,4$ & $7,0-7,4$ & $6,5-7,2$ \\
$\mathbf{N H}_{\mathbf{3}}(\mathbf{p p m})$ & $0,030-0,044$ & $0,045-0,047$ & $0,040-0,048$ & 0,003 \\
$\mathbf{C O}_{\mathbf{2}}(\mathbf{p p m})$ & $1,90-1,98$ & $1,57-1,98$ & 1,98 & 2,00 \\
\hline
\end{tabular}

Pengamatan gejala klinis dilakukan dengan mengamati luka dan mortalitas benih gurami akibat infeksi bekteri A. hydrophila. Gejala klinis awal yang teramati berupa peradangan (inflamasi) yang dicirikan dengan pembengkakan dan warna merah pada bekas luka suntikan. Gejala ini terlihat merata pada semua benih gurami yang dilakukan infeksi buatan (penyuntikan). Gejala lain pada benih

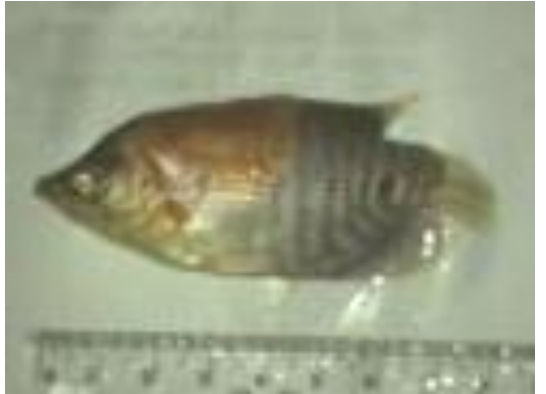

(a) yang sudah diinfeksi bakteri $A$. hydrophila yaitu ikan terlihat stress, bergerak/berada di sekitar aerasi, berenang dengan posisi tubuh miring dan nafsu makan turun bahkan sampai tidak mau makan. Setiaji (2009) melaporkan bahwa ikan yang disuntik dengan bakteri $A$. hydrophila secara intramuscular akan mengalami hilangnya nafsu makan dan perubahan patogenitas.

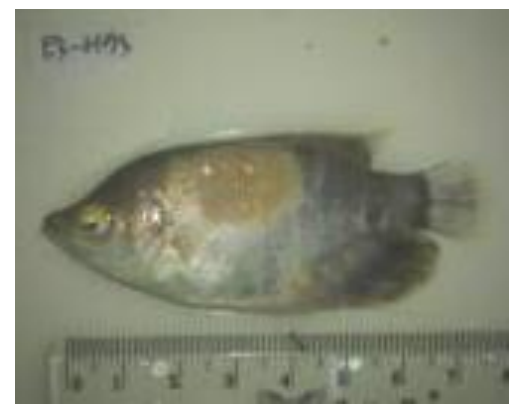

(b)

Gambar 1. Benih gurami yang terinfeksi bakteri Aeromonas hydrophila (a) 9 jam pasca penyuntikan (b) 93 jam pasca penyuntikan

Kematian ikan yang diberi perlakuan sudah terjadi di hari pertama lebih tepatnya pada jam ke-8. Pada perlakuan E mortalitas tertinggi terjadi pada hari pertama dan menurun pada hari berikutnya. Perlakuan B, C dan $\mathrm{D}$ terjadi peningkatan mortalitas dari hari pertama ke hari kedua, namun pada hari selanjutnya terjadi penurunan kembali sampai hari ke-4.

Menurut Reed dan Muench (1938) dalam Setiaji (2009) $\mathrm{LD}_{50}$ adalah dosis yang dapat mematikan $50 \%$ dari jumlah hewan percobaan dalam waktu tertentu. Berdasarkan hasil uji $\mathrm{LD}_{50}$ bakteri $A$. hydrophila terhadap benih gurami (Tabel 1) dosis bakteri yang dapat mematikan $50 \%$ populasi benih gurami pada penelitian ini tidak terlihat, namun terlihat dosis yang mendekati $\mathrm{LD}_{50}$ yaitu terdapat pada dosis $10^{4}$ sel $/ \mathrm{mL}$ (perlakuan B) dengan mortalitas sebesar $63,33 \%$. Oleh karena itu dosis $10^{4} \mathrm{sel} / \mathrm{mL}$ akan digunakan pada perlakuan selanjutnya yaitu pada uji tantang pertama.

Pada Tabel 1 memperlihatkan bahwa semakin tinggi dosis bakteri yang digunakan maka semakin tinggi pula mortalitasnya, dosis $10^{7} \mathrm{sel} / \mathrm{mL}$ dapat mematikan benih gurami sebanyak $98,33 \%$, perlakuan B sebesar $63,33 \%$ dan terlihat pada tubuh benih gurami mengalami peradangan dan hemorrhagic septicemia, artinya mortalitas benih gurami pada uji $\mathrm{LD}_{50}$ ini disebabkan oleh bakteri $A$. hydrophila yang virulen terhadap benih gurami sedangkan pada perlakuan A sebagai kontrol memberikan hasil mortalitas sebesar 1,67\% dan tidak terjadi peradangan. Konsentrasi $A$. 
hydrophila $10^{7} \mathrm{cfu} / \mathrm{mL}$ dapat mematikan ikan lele dumbo sebesar $100 \%$, konsentrasi $10^{6}$ $\mathrm{cfu} / \mathrm{mL}$ sebesar $88 \%$, konsentrasi $10^{5} \mathrm{cfu} / \mathrm{mL}$ sebesar $67 \%$ dan konsentrasi $10^{4} \mathrm{cfu} / \mathrm{mL}$ sebesar $17 \%$ (Setiaji 2009). Semakin tinggi dosis yang disuntikkan mengakibatkan serangan lebih tinggi sehingga mengakibatkan kematian yang semakin tinggi dan ikan menderita motile aeromonas septicemia, hal ini terjadi karena daya tahan tubuh ikan gurami tersebut lebih rendah dari potogenitas bakteri (antigen).

\section{Mortalitas Benih Gurami Pasca Penyuntikan Dengan Aeromonas hydrophila}

Perkembangan tingkat kematian benih gurami setelah dilakukan uji tantang pertama dengan $\mathrm{LD}_{50}$ bakteri Aeromonas hydrophila akan memperlihatkan tingkat ketahanan benih gurami, benih gurami yang diberi perlakuan rosella memiliki ketahanan tubuh yang lebih tinggi dan berbeda sangat nyata dengan benih gurami tanpa perlakuan $(\mathrm{P}<0,01)$. Dosis rosella $20 \mathrm{gram} / \mathrm{kg}$ pakan tidak memberikan pengaruh yang nyata terhadap ketahanan benih gurami yang diberi dosis rosella 30 gram $/ \mathrm{kg}$ pakan $(\mathrm{P}>0,01)$. Benih gurami yang diberi perlakuan (rosella) memiliki ketahanan tubuh yang lebih tinggi daripada benih gurami yang tidak diberi perlakuan, artinya antibakteri dan vitamin $\mathrm{C}$ yang terkandung dalam bunga rosella yang diberikan kepada benih gurami dapat dimanfaatkan sebagai imunostimulan sehingga dapat meningkatkan daya tahan tubuh benih gurami.

Setelah dilakukan uji tantang pertama selesai selajutnya benih gurami dilakukan kembali uji tantang kedua dengan lama waktu yang sama pada uji tantang pertama yaitu 96 jam, namun dosis bakteri $A$. hydrophila yang digunakan ditingkatkan 10 kali lipat dari uji tantang pertama yaitu $10^{5} \mathrm{sel} / \mathrm{mL}$. Peningkatan dosis ini dilakukan karena diduga ketika benih gurami diinfeksikan bakteri A. hydrophila pada saat uji tantang pertama secara alami imunitas ikan sudah mengenali antigen tersebut, maka dilakukan peningkatan dosis menjadi $10^{5} \mathrm{sel} / \mathrm{mL}$ untuk mengetahui peningkatan ketahanan benih lebih lanjut. Ketahanan benih gurami yang diinfeksikan bakteri $A$. hydrophila dosis $10^{5} \mathrm{sel} / \mathrm{mL}$ dapat dilihat melalui perkembangan tingkat kematian dan mortalitas ikan setelah dilakukan uji tantang kedua.

Tabel 3 memperlihatkan tingkat ketahanan benih gurami, benih gurami yang diberi perlakuan rosella memiliki ketahanan tubuh yang lebih tinggi dan berbeda sangat nyata $(\mathrm{P}<0,01)$ dengan benih gurami tanpa perlakuan (kontrol). Dosis rosella $20 \mathrm{gram} / \mathrm{kg}$ pakan tidak memberikan pengaruh yang nyata terhadap ketahanan benih gurami yang diberi dosis rosella 30 gram $/ \mathrm{kg}$ pakan $(\mathrm{P}>0,01)$. Antibakteri dan vitamin $\mathrm{C}$ yang terkandung dalam bunga rosella yang diberikan kepada benih gurami pada perlakuan $\mathrm{B}$ dan $\mathrm{C}$ dapat dimanfaatkan sebagai imunostimulan sehingga dapat meningkatkan daya tahan tubuh lebih cukup dari perlakuan A.

\section{Total Sel Darah Putih (Leukosit)}

Diagnosa suatu penyakit atau tingkat kesehatan pada ikan dapat ditentukan dengan melihat perubahan darah ikan, baik secara kualitatif maupun kuantitatif. Wedemeyer et al. (1990) menjelaskan bahwa pemeriksaan darah penting untuk membantu peneguhan diagnosa suatu penyakit. Jumlah total leukosit pada ikan air tawar normal yaitu 20.000$150.000 \mathrm{sel} / \mathrm{mm}^{3}$ (Burhanuddin 2008), Ilmiah et al. (2002) melaporkan jumlah total leukosit pada ikan jambal berkisar antara 21.160$25.910 \mathrm{sel} / \mathrm{mm}^{3}$ dan pada penelitian Dopongtonung (2008) melaporkan rataan total leukosit pada ikan lele sebesar 143,5 $\pm 7,01 \mathrm{x}$ $10^{3} \mathrm{sel} / \mathrm{mm}^{3}$.

Rataan total leukosit sebelum uji tantang pertama sangat tinggi bila dibandingkan dengan rataan total leukosit pada ikan lain, hal ini diduga ikan mengalami stress atau leukemia. Anderson dan Siwicki (1993) menerangkan bahwa ikan yang terkena leukemia, stres atau adanya infeksi akan menunjukkan terjadinya peningkatan jumlah leukosit pada darah ikan. Pemberian bunga rosella kepada benih gurami memberikan pengaruh dalam peningkatan rataan leukosit. Rataan total leukosit tertinggi sebelum uji tantang berada pada perlakuan B sebesar 5,450 x $10^{5} \mathrm{sel} / \mathrm{mm}^{3}$ sedangkan rataan terendah pada perlakuan A (kontrol) sebesar 4,920 × $10^{5}$ $\mathrm{sel} / \mathrm{mm}^{3}$. 
Setelah dilakukan uji tantang pertama terjadi perubahan rataan total leukosit pada setiap perlakuan. Pada perlakuan A rataan total leukosit meningkat menjadi $6,485 \times 10^{5}$ $\mathrm{sel} / \mathrm{mm}^{3}$, perlakuan $\mathrm{B}$ meningkat menjadi $6,930 \times 10^{5} \mathrm{sel} / \mathrm{mm}^{3}$ dan perlakuan $\mathrm{C}$ meningkat dari $5,248 \times 10^{5} \mathrm{sel} / \mathrm{mm}^{3}$ menjadi $5,88810^{5} \mathrm{sel} / \mathrm{mm}^{3}$. Rataan total leukosit tertinggi terdapat pada perlakuan B. Peningkatan jumlah leukosit benih gurami setelah uji tantang menunjukkan adanya penyakit infeksi tertentu yang menyerang ikan. Tingginya rataan total leukosit pada perlakuan B memberikan gambaran pertahanan tubuh gurami juga tinggi. Dengan perlakuan pemberian rosella pada benih gurami membantu sel leukosit dalam mengurangi jumlah dan patogenitas dari bakteri $A$. hydrophila (antigen). Mulyani (2006) menambahkan bahwa leukosit akan berpindah aktif ke daerah yang mengalami infeksi dan cenderung terjadi peningkatan saat terjadi infeksi.

Rataan total leukosit setelah uji tantang kedua masih memperlihatkan peningkatan rataan total leukosit pada perlakuan A dan C, tetapi pada perlakuan $\mathrm{B}$ memperlihatkan penurunan. Peningkatan leukosit pada perlakuan A dan $\mathrm{C}$ memperlihatkan bahwa benih gurami setelah diinfeksikan bakteri $A$. hydrophila masih membutuhkan leukosit dalam jumlah yang banyak, berbeda dengan perlakuan B yang menghasilkan leukosit lebih sedikit. Arry (2007) melaporkan bahwa peningkatan jumlah leukosit total terjadi akibat adanya respon dari tubuh ikan terhadap kondisi lingkungan, faktos stress dan infeksi penyakit. Hal ini menunjukkan bahwa rosella berfungsi memberikan rangsangan pertahanan lebih baik daripada benih yang tidak diberi rosella dan pertahanan tubuh terbaik gurami pada perlakuan C. Hasil uji aktivitas antibakteri pada penelitian Rostianawati (2009) menunjukkan bahwa bunga rosella mempunyai aktivitas sebagai antibakteri dan memiliki vitamin $\mathrm{C}$ yang berfungsi sebagai imustimulan. Pada perlakuan $\mathrm{C}$ diduga telah terjadi pembentukan sistem pertahanan spesifik yang melibatkan sel limfosit T (sel T) pada leukosit. Sistem pertahanan spesifik membutuhkan waktu untuk mengenal antigen terlebih dahulu sebelum dapat memberikan respon (Purwanto 2006).

\section{Total Sel Darah Merah (Eritrosit)}

Kadar eritrosit dalam darah dapat dijadikan indikator kesehatan ikan, rendahnya eritrosit menandakan ikan dalam keadaan anemia, sedangkan kadar eritrosit yang tinggi menandakan ikan dalam keadaan stres. Wedemeyer dan Yustake (1977) dalam Dopongtonung (2008) menjelaskan bahwa anemia terjadi karena rendahnya eritrosit dan stress diakibatkan tingginya eritrosit pada darah ikan.

Jumlah eritrosit pada ikan teleostei berkisar antara $(1,05-3,0)$ x $10^{6} \mathrm{sel} / \mathrm{mm}^{3}$, jumlah eritrosit pada ikan lele (Clarias ssp) adalah $3,18 \times 10^{6} \mathrm{sel} / \mathrm{mm}^{3}$ dan pada penelitian Vonti (2008) melaporkan jumlah eritrosit pada ikan mas strain sinyonya berkisar antara $(1,67-$ $4,47) \times 10^{6} \mathrm{sel} / \mathrm{mm}^{3}$.

Secara keseluruhan rataan total eritrosit selama penelitian dalam keadaan normal. Rataan eritrosit sebelum uji tantang pertama yaitu berkisar antara $(1,608-1,880)$ x $10^{6}$ $\mathrm{sel} / \mathrm{mm}^{3}$. Rataan tertinggi terdapat pada perlakuan $\mathrm{C}$ dan terendah pada perlakuan $\mathrm{B}$. Rataan eritrosit setelah uji tantang pertama berkisar antara $(1,703-1,760) \times 10^{6} \mathrm{sel} / \mathrm{mm}^{3}$. Rataan eritrosit setelah uji tantang kedua berkisar antara $(1,720-2,043) \times 10^{6} \mathrm{sel} / \mathrm{mm}^{3}$. Rataan tertinggi terdapat pada perlakuan $\mathrm{C}$ dan terendah pada perlakuan B. Perlakuan C memberikan nilai terbaik untuk rataan total eritrosit benih gurami. Peningkatan jumlah eritrosit pada ikan yang diberi rosella disebabkan karena pada rosella terdapat senyawa asam amino (arginin dan legnin) yang berfungsi sebagai peremajaan sel tubuh.

Jumlah rataan eritrosit yang normal menandakan ikan dalam keadaan sehat, dimana fungsi darah dalam mengangkut oksigen $\left(\mathrm{O}_{2}\right)$ dari luar tubuh menuju organ-organ yang memerlukan dan membuang karbondioksida $\left(\mathrm{CO}_{2}\right)$ ke luar tubuh tidak terganggu. Hal ini memperlihatkan bahwa rosella dapat memperlancar peredaran darah pada benih gurami. Pada perlakuan $\mathrm{C}$ terlihat adanya penurunan rataan total eritrosit setelah uji tantang pertama, namun naik kembali setelah uji tantang kedua. Hal ini terjadi karena pada saat uji tantang kedua benih gurami sudah 
memiliki ketahanan tubuh terhadap serangan A. hydrophila.

\section{Konsentrasi Hemoglobin (Hb)}

Hemoglobin merupakan bagian dari eritrosit, dimana fungsi hemoglobin sebagai pengangkut oksigen dan karbondioksida. Moyle dan Cech (1988) dalam Vonti (2008) menjelaskan fungsi hemoglobin sebagai alat transport oksigen dan karbondioksida yang terdapat dalam eritrosit. Konsentrasi hemoglobin ikan lele sebesar 6,1 \pm 0,88 gram\% (Dopongtonung 2008), konsentrasi hemoglobin ikan gurami pada penelitian Mulyani (2006) berkisar antara 3,07-5,93 gram\%.

Rataan kadar hemoglobin sebelum uji tantang pada perlakuan kontrol sebesar 4,60 gram $\%$, perlakuan B sebesar 4,85 gram $\%$ dan perlakuan $\mathrm{C}$ sebesar 6,25 gram\% sekaligus menduduki peringkat kadar hemogbloin terbesar. Rataan hemoglobin setelah uji tantang meningkat pada perlakuan A dan B, kecuali perlakuan $\mathrm{C}$ yang mengalami penurunan. Perlakuan B memberikan hasil terbesar rataan hemoglobin setelah uji tantang pertama sebesar 6,45 gram $\%$. Peningkatan kadar hemoglobin terjadi karena ikan yang terinfeksi bakteri Aeromonas hydrophila mengalami pendarahan (hemoragi) pada bekas luka suntikan. Mulyani (2006) melaporkan bahwa ikan mengalami hemoragi pada saat ikan sedang terinfeksi cendawan dan spora dengan dosis tinggi dan menyebabkan hemoglobin ikan meningkat. Rataan tertinggi hemoglobin setelah uji tantang kedua berada pada perlakuan $\mathrm{C}$, dimana perlakuan $\mathrm{C}$ sebelum uji tantang kedua memiliki hemoglobin lebih besar. Hal ini diduga pendarahan yang terjadi semakin membesar. Sebaliknya terjadi pada perlakuan $\mathrm{B}$, dimana kadar hemoglobinnya menurun setelah uji tantang kedua. Hal ini diduga benih ikan memiliki ketahanan yang lebih baik sehingga pendarahan yang terjadi menurun dan ikan sudah mengalami penyembuhan. Rataan hemoglobin yang normal menandakan bahwa proses transportasi pengangkutan oksigen dan karbondioksida di dalam plasma darah tidak mengalami gangguan pada saat ikan diuji tantang. Pada pengamatan kadar hemoglobin dapat dilihat bahwa rosella mampu meningkatkan kadar hemoglobin benih gurami, hal ini terjadi karena senyawa antibakteri pada rosella mampu melawan antigen yang masuk sehingga Fe pada eritrosit tidak dapat dipakai oleh antigen dan $\mathrm{Fe}$ dalam eritrosit mampu mengikat oksigen secara maksimal oleh homoglobin.

\section{Kadar Hematokrit (Ht)}

Hematokrit dipengaruhi oleh jumlah eritosit dalam darah dan merupakan presentase eritrosit dalam darah. Kadar hematokrit ikan teleostei berkisar antara 20-30\% (Bond 1979 dalam Mulyani 2006). Penelitian Dopongtonung (2008) melaporkan nilai hematokrit ikan lele berkisar antara $13-24 \%$, nilai hematokrit ini lebih rendah dari kisaran normal pada penelitian Angka et al. (1985) dalam Dopongtonung (2008) yang menunjukkan pada kisaran 30,8-45,5\%. Rendahnya hematokrit disebabkan ikan mengalami anemia. Mulyani (2006) melaporkan nilai hematokrit ikan gurami kontrol pada penelitiannya berkisar 33-43\%. Nabib dan Pasaribu (1989) menyatakan bahwa kadar hematokrit di bawah $30 \%$ menunjukan defisiensi eritrosit. Rataan kadar hematokrit terbesar sebelum uji tantang pertama berada pada perlakuan $\mathrm{C}$ sebesar $16,50 \%$ dan terkecil pada perlakuan B sebesar 14,39\%, setelah uji tantang pertama rataan kadar hematokrit terbesar pada perlakuan B $(22,14 \%)$ dan terkecil pada perlakuan A $(17,20 \%)$. Rataan kadar hematokrit terbesar setelah uji tantang kedua berada pada perlakuan B $(21,23 \%)$ dan terendah pada perlakuan A $(19,27 \%)$ sebagai kontrol.

Secara umum, rataan hematokrit pada saat penelitian dinilai kecil dan diduga rendahnya nilai hematokrit ini karena ikan mengalami anemia, defisiensi nutrisi dalam pakan dan terserang penyakit infeksi. Dellman dan Brown (1989) dalam Mulyani (2006) menyatakan bahwa hematokrit akan menurun ketika ikan terkena infeksi. Setelah uji tantang pertama terlihat rataan hematokrit pada perlakuan A (kontrol) nilainya paling rendah dibandingkan dengan perlakuan $\mathrm{B}$ dan $\mathrm{C}$, begitu pun rataan setelah uji tantang pertama perlakuan A memiliki nilai paling rendah, hal ini menunjukkan bahwa ada pengaruh 
pemberian rosella sebagai imustimulan kepada benih gurami terhadap nilai hematokrit ketika ikan terinfeksi bakteri A. hydrophila. Andeson dan Siwicki (1993) menerangkan bahwa imunostimulan berpengaruh terhadap nilai hematokrit walaupun dengan prosentase yang kecil. Rataan nilai hematokrit terbaik berada pada perlakuan B.

\section{KESIMPULAN DAN SARAN \\ Kesimpulan}

Berdasarkan penelitian yang dilakukan, pemberian bunga rosella pada pakan buatan berpengaruh terhadap mortalitas, jumlah leukosit, jumlah eritrosit, kadar hemoglobin, kadar hematokrit dan indeks fagositik benih ikan gurami.

Dosis rosella yang mampu memberikan peningkatan daya tahan tubuh gurami terbaik diperoleh pada perlakuan C (rosella 30 gram $/ \mathrm{kg}$ pakan) dengan mortalitas sebesar $8,26 \%$, total leukosit sebesar $6,873 \times 10^{5}$ $\mathrm{sel} / \mathrm{mm}^{3}$, total eritrosit sebesar $2.043 \times 10^{6}$ $\mathrm{sel} / \mathrm{mm}^{3}$, kadar hemoglobin sebesar 6,55 gram $\%$, nilai hematokrit sebesar $20,59 \%$ dan indeks fagositik sebesar 64\%. Pemberian rosella pada pakan dapat meningkatkan ketahanan tubuh dan menurunkan mortalitas benih gurami.

\section{Saran}

Diperlukan penelitian lanjutan dengan menaikkan dosis rosella dari dosis yang memberikan ketahanan terbaik, kemudian dilihat kembali mortalitas dan gambaran darahnya.

\section{DAFTAR PUSTAKA}

Afrianto E, Liviawaty E. 1999. Pengendalian Hama dan Penyakit Ikan. Yogyakarta : KANISIUS.

Anderson DP, Siwicky AK. 1993. Basic Haematology and Serology for Fish Health Program. Paper Presented in Second Symposium on Disease in Asia Aquaculture Aquatic Animal Health and Eviroment Phuket Thailand.

Arry. 2007. Pengaruh Suplementasi Zat Besi

(Fe) Dalam Pakan Buatan Terhadap
Kinerja Pertumbuhan dan Imunitas Ikan Kerapu Bebek (Cromileptes altivelis). Skripsi. Fakultas Perikanan Dan Ilmu Kelautan. Institut Pertanian Bogor.

Blaxhall PC, Daisley KW. 1973. Routine Haematological Methods For Use Alt Fish Blood. Fish Biology 5: 577-581.

Burhanuddin AI. 2008. Peningkatan Pengetahuan Konsepsi Sistematika dan Pemahaman Sistem Organ Ikan yang Berbasis SCL Pada Mata Kuliah Ikhtiologi. Fakultas Ilmu Kelautan dan Perikanan Universitas Hasanuddin. Makassar.

Chrisanti RA, Sulmartiwi L, Prayogo. 2012. Efektifitas Perasan Asam Jawa (Tanarindus indica L.) Terhadap Pertumbuhan Bakteri Aeromonas hydrophila dengan Matode Difusi Kertas Cakram. Jurnal Ilmiah Perikanan dan Kelautan Vol. 4, No. 2, Hal.10-17.

Dopongtonung A. 2008. Gambaran Darah Ikan Lele (Clarias spp) Yang Berasal Dari Daerah Laladon-Bogor. Skripsi. Fakultas Kedokteran Hewan, Institut Pertanian Bogor. Bogor.

Hesser EF. 1960. Methods for Routine Fish Hematology. $\quad \mathrm{P}^{+}$sssive Fish Culturist.

Ilmiah. 1999. Peranan Vitamin C Dalam Meningkatkan Kekebalan Ikan Jambal Siam (Pangasius hypophthalmus Fowler, Roberts and Vidthayanon 1991). Tesis. Program Pascasarjana, Institut Pertanian Bogor. Bogor.

Ilmiah, Dana D. Pasaribu FH, Affandi R. 2002. Peranan Asam Askorbik Dalam Meningkatkan Imunitas Ikan Jambal Siam (Pangasius hypopthalmus Fowler). Desertasi. Fakultas Perikanan dan Kelautan UMI Makassar. Indonesia. 
Khairuman, Amri K. 2011. Pembesaran Gurami Secara Intensif. Jakarta : Agromedia.

Mulyani S. 2006. Gambaran Darah Ikan Gurame Osphronemus gouramy Yang Terinfeksi Cendawan Achlya sp. Pada Kepadatan 320 Dan 720 Spora Per mL. Skripsi. Fakultas Perikanan dan Ilmu Kelautan, Institut Pertanian Bogor. Bogor.

Mustikhasary A. 2013. Penambahan Bunga Rosella (Hibiscus sabdariffa L) Pada Pakan Terhadap Ketahanan Tubuh Ikan Gurami (Osphronemus gouramy) yang Diuji Tantang dengan Bakteri Aeromonas hydrophila. Skripsi. Universitas Djuanda Bogor. Bogor.

Neni. 2010. Manfaat Bunga Rosella Bagi Kesehatan. Universitas Muhamadiyah Malang. Malang.

Purwanto A. 2006. Gambaran Ikan Mas (Cyprinus carpio) yang Terinfeksi Koi Herpes Virus. Skripsi. Fakultas Perikanan dan Ilmu Kelautan, Institut Pertanian Bogor. Bogor
Rostianawati T. 2009. Aktivitas Antibakteri Ekstrak Etanol Bunga Rosella (Hibiscus sabdariffa L.) Terhadap Escherichia coli, Salmonella typhi dan Staphylococcus aureus dengan Metode Difusi Agar. Penelitian Mandiri. Fakultas Farmasi Universitas Padjadjaran Jatinangor. Sumedang.

Setiaji A. 2009. Efektifitas Ekstrak Daun Pepaya Carica papaya L. Untuk Pencegahan dan Pengobatan Ikan Lele Dumbo Clarias sp yang Diinfeksi Bakteri Aeomonas hydrophila. Skripsi. Fakultas Perikanan dan Ilmu Kelautan, Institut Pertanian Bogor. Bogor.

Still RG, Torrie JH. 1991. Prinsip dan Prosedur Statistika : Suatu Pendekatan Biometik. Jakarta : Gramedia Pustaka Utama.

Vonti O. 2008. Gambar Darah Ikan Mas (Cyprinus carpio Linn) Strain Sinyonya Yang Berasal Dari Daerah CiampeaBogor. Skripsi. Fakultas Kedokteran Hewan, Institut Pertanian Bogor. Bogor. 